\title{
The Fitting Factor in Komarudin's Pattern
}

\author{
Hapsari Kusumawardani ${ }^{1}$ Siti Zahro ${ }^{2}$ Mirenda Ekaning Setiawan ${ }^{3}$ \\ ${ }^{1,2,3}$ Department of Industrial Technology, Universitas Negeri Malang, Indonesia.
}

\begin{abstract}
Fit is one of the important aspects to consider in wearing any model of clothes. It often brings customers with problems about choosing men's clothes, especially in choosing formal clothes. The purpose of this study is to know the fitting factors in Komarudin's Pattern focusing in shirt patterns. The fitting points used in this study include the measurements of (1) the neck, (2) the shoulders, (3) the back width, (4) the chest, (5) the waist, and (6) the arm lenght. This study is qualitative research using the descriptive approach through interviews and observations. It involved three experts in pattern making and fashion practitioners to hold a focus group discussion (FGD). Besides, three models participated in it to try the shirt made in Komarudin's pattern. The results of this study showed that the neck, the first fitting point, is unfit to be worn by all of the models because in Komarudin's pattern the collar is made so small that the models felt uncomfortable to wear it. The FGD came up with the corroborating evidence that the neck brackets in Komarudin's pattern are too small. As for other fitting points, the results showed that all of the other fitting points are fit to wear, which means posing no problem. Based on the results, it can be concluded that the Komarudin's pattern is in need of being combined with other patterns, especially in fitting points of the neck and the collar.
\end{abstract}

Keywords: fitting factor, men's wear, pattern

\section{INTRODUCTION}

The course of techniques for making men's clothes is offered to the fifth-semester students of Fashion Department of Malang State University.The course expects students to be competent produce men's clothes made of any fabric materials using proper sewing techniques and analyze models of men's clothes made for any special occasion. One of the expected competencies is that students can make patterns of men's clothes such as shirts, koko shirts, pajamas, and trousers.

Some sewing training centers likewise have their own patterns of making shirts. The difference lies in the way they make parts of shirts including neckline, collars, sleeves and body patterns, which all affects collars' position as well as comfort and beauty of the shirt if worn.We can take patterns Komaruddin developed in the training center to which The Youth and Sports Service (DISPORA) entrust the task of dress shirt construction.Patterns made under this system, of course, have their own advantages and disadavantages, especially when used to make men's shirts in the standard sizes of S, $\mathrm{M}$, and $\mathrm{L}$

In general, shirt patterns made standard with different sizes of full-grown men's body measurements tend to a particular system of shirt constructing patterns, although the system has its advantages and disadvantages because of dissimilar steps and calculations. On the one hand, according to Pratiwi (2001:16), the advantage of constructional patterns is to have a pattern similar to someone's body shape, which is instrumental in sewing clothes. For instance, the seams of bra cups are sewn based on the users' breast size in comparison with their body measurement. On the other hand, Pratiwi (2001) stated that patterns pose some difficulties to sewers: they have difficulties drawing the patterns and printing them onto fabrics, while, in fact, it takes long time for them to train themselves to know the disadvantages of the chosen pattern. Given the aforementioned facts, this research aims to find out what is likely to happen if patterns developed by Komaruddin are applied to making shirts in S, M, and $\mathrm{L}$ sizes by taking into account fitting factors in those patterns.

\section{LITERATURE REVIEW}

\subsection{Shirts}

In the Great Dictionary of Indonesian Language, usually abbreviated as KBBI, (2013) the term "shirt" refers to men's collared button front dress made usually of cotton or linen, some long-sleeved, some short-sleeved.

The beauty and comfort of shirts rely strongly on the pattern used. Shirt patterns are templates from which any other styles and models are developed based on desires and demands of the users.

In their manufacturing process, shirts can be made according to the users' body measurement under the constructional system or in the standard sizes of S, M, L, and XL or in other greater sizes.

\subsection{Shirt Patterns}

A pattern is a piece of fabric or paper used as a template of one's body measurement useful for dressmaking, especially in cutting fabric materials (Sugiyem, 2008). 
Muliawan P. (1992:2) likewise defined the fashion term "pattern" as a piece of fabric or paper which is finely adjusted to certain body measurements to be used in cutting materials in sewing processes. In practice, shirt patterns as templates can be made of fabric using a particular measurement and chosen manfufacturing system.

\subsubsection{Shirt Construction in Komarudin's Pattern}

The development of men's fashion products has given a rise to the making of basic patterns of shirts. Choosing shirt patterns streamlines the shirt-manufacturing process. Each person has his/her personal preference toward a particular pattern system. Given their different body shapes and sizes, people take into consideration the ease of dressmaking process and the preference in the designed pattern in sewing shirts.

Shirt construction patterns are those made on a body measurement basis. Drawing patterns may bagin with precisely measuring front and back sides of the body, the
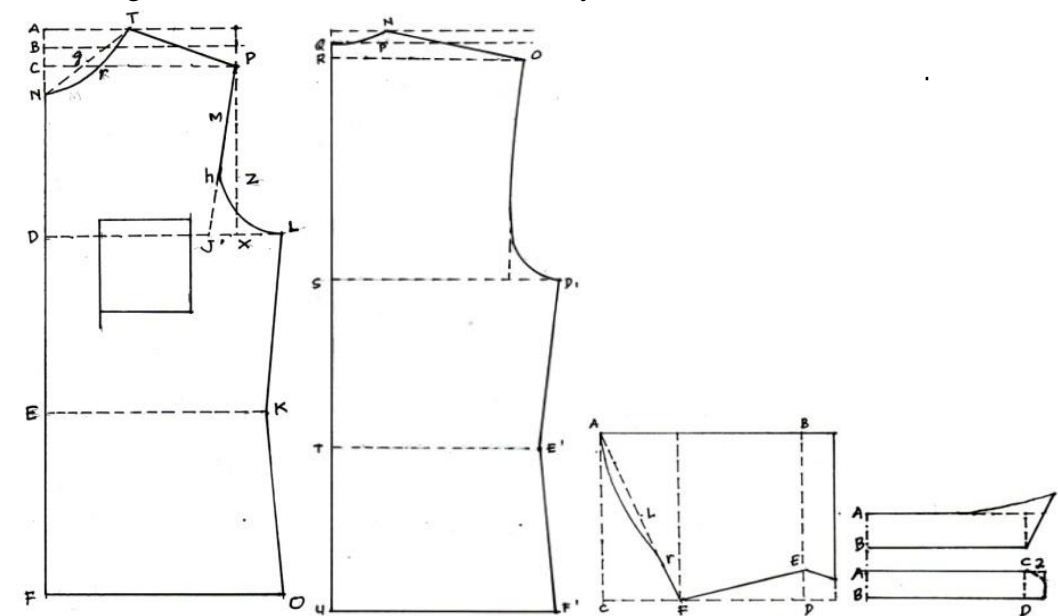

Figure 2.3. Komarudin Pattern-Making Sytem (scale: 1:4)

Source : Module of DISPORASewing Training Program (1988)

\subsection{Position Of Fitting Factor Of Shirts}

Well-manufactured shirts are those with the fitting factors locating in their exact position. The exact position of the fitiing factors can be accurately located by considering one stage of the sewing processes, i.e. pressing, in accordance with the shirt size.

The fitting factor forms a point of clothes by which to determine whether or not the clothes fit the users'body measurements (Prahastuti, 2004). Shirts' fitting factor deals with positions of (1) neckline, (2) shoulder, (3) back width, (4) body circumference, (5) waist circumference, and (6) sleeves. Fitting factor is determined according to precise measurement of each pattern. Murbeng's research (2011) shows according to the criteria for kebaya pattern (neckline, shoulder, waist circumference, cup seams, back width, and pelvis circumference) that fitting factors in Mayneke's pattern is accurate and comfortable. neckline, the sleeves, the wrists, etc. Taylors have different shirt manufacturing systems. Students of Fashion Departments and sewing training centers are likewise taught various patterns, procedures, and methods for making shirts.

Generally, the first step in the shirt-making process is to make the pattern of the front body side, on which is that of the back side based. Meanwhile, the patterns of the rest are made afterwards. This pattern-making system, in which shoulder pads and necklines are measured in in the same size, is so simple that the sewer does not need to take too many measurements.

Komarudin pattern-making system needs 7 body measurements which involve some precautionary steps. The first step is to make the pattern of the front bodice and then connect it with the back-bodice pattern. The waist part is made narrower than the hip part, while front sleeve pattern is made more cuved than the back one.Besides, there are helping lines to measure shoulder height. The sleeve lines are used as the mirror image of its hem. Both the front and the back of the bottom are made flat.

Shirt construction needs some measurements in standardized sizes and those in each desired making system. Each system has its own method of taking measurements and making patterns.

\section{RESEARCH METHOD \\ 3.1 Research Plan}

Based on the research purpose to know the potential utility of Komarudin's pattern if applied to standardized body sizes of $\mathrm{S}, \mathrm{M}$, and $\mathrm{L}$ by studying its fitting factors, the researcher conducted qualitative research using descriptive approach. Focus Group Discussion (FGD) was used as the method for analyzing and solving the problem related to locate fitting factor of different patterns of shirt sizes using a number of set items.

The team of Focus Group Discussion (FGD) is a group consisting of researcher team and authoritative, informed sources holding extensive discussion during the research 
The object of this research consists of standard-sized shirts and constructionally-made ones. Another object is model body measurements equal to men's stardard S, M, and L sizes. Subsequently, the model body measurements are used in a shirt-making process using Komarudin's patternmaking system. Accordingly, there are three pieces of shirts in total. Each is made in different colors in order to avoid possible confusion among the three shirts concerning the color use.

In view of the fact that the data are obtained from three reliable sources: a fashion expert also lecturing on men's fashion products, tailoring, and an expert in pattern construction, the researcher uses triangulation for data analyses.

\subsection{Research Instruments}

Based on the set research plans, the researcher listed some items to guide the data-collecting process from FGD. The listed items are as follows.

\subsection{Data Sources}

Table 1. Research Instrument

\begin{tabular}{|c|c|c|}
\hline Research Focus & Indicators & Sub-indicators \\
\hline \multirow[t]{5}{*}{$\begin{array}{l}\text { Fitiing factors in } \\
\text { Komarudin's pattern- } \\
\text { making system }\end{array}$} & Sizes & $\begin{array}{l}\text { - S-like size } \\
\text { - M-like size } \\
\text { - L-like size }\end{array}$ \\
\hline & Body measurements & $\begin{array}{l}\text { - Body Circumference } \\
\text { - Waist Circumference } \\
\text { - Hip Circumference } \\
\text { - Back width } \\
\text { - Shoulder level }\end{array}$ \\
\hline & Collars & $\begin{array}{l}\text { - Collar position } \\
\text { - Collar shape }\end{array}$ \\
\hline & Sleeves & $\begin{array}{l}\text { - Arm length } \\
\text { - Sleeve circumference } \\
\text { - Wrist circumference }\end{array}$ \\
\hline & Size match & $\begin{array}{l}\text { - Position of pockets } \\
\text { - Shirt length }\end{array}$ \\
\hline
\end{tabular}

Discussion of FGD was held by the researcher team along with an expert fashion who is a lecturer in theory and practice of fashion. The researcher used two types of triangulation: methodological triangulation and data triangulation.

The methodological triangulation deals with datacollecting methods: observations, interviews, and documents, while the data triangulation deals specifically with the involved, informed sources, including a lecturer expert in basic patterns, an expert in grading techniques, and a men's dress making expert. Through observation, the researcher carried out an assessment of shirt position and condition on the basis of listed questions realting to fitiing factors in Komarudin's pattern-making system.

Interviews were conducted to gain information from the experts and models serving as the research object, and documentswere produced by taking pictures of the models' wearing the shirts resulting from the application of Komarudin's system.

\subsection{Data Collection and Analysis}

Research data were collected from the results of the group discussion focusing on the research topic result in the form of written documents and pictures of shirts worn by the models. The collected data were reduced, which had nothing to do with the research focus and the set indicators of pattern-making system and those of fitiing-factor assessment.

\subsection{Data Analysis / Data Validation}

Data analysis was made by focusing on the position offitting factors of shirts the models wore in proportion to their size.Only when the fitting factors are in their 


\section{RESULTS AND DISCUSSION}

This qualitative research involved 3 fashion figures expert in theory and practice of fashion, in tailoring, and in pattern construction respectively.In addition, it also appointed three employees of Faculty of Engineering of Malang State University as models designated to wear thes shirts made in this research process in sizes equal to the standard S, M, and L sizes.

The research, conducted in Necklinlaboratorium of Industrial Engineering Department of Faculty of Engineering of Malang State University, collected data using such methods as observations, interviews, and documents.

\subsection{Shirts Made Under Komarudin's System In Terms Of Fitting Factor}

This research examined shirts made under Komarudin's system which has on DISPORA's recommendation been taught to students. Those shirts were made in standard pattern: equipped with collars, sleeves, and pockets. The position of fitting factors, meanwhile, was determined by some measurements including body circumference, collar position, neckline, back width, sleeve circumference, wrist circumference, pelvis circumference, and shirt length. Furthermore, collar shapes, types of sleeves, waist shapes, pocket position, and comforting quality form other assessment criteria in shirt-making system.

\subsection{Shirt Models and the Analysis Result}

Each of the shirts was made in the standard: collared, short-sleeved board shirts with a pocket on the left chest. The following is the result of the research observation.

\section{a. Shirt Picture}

The shirts were made using models and measurements in Komarudin's system. Here are the shirt models.

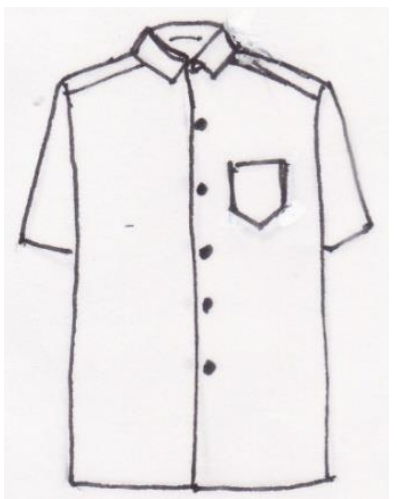

Figure 4.1. Shirt Model 


\section{b. The Analysis Result of S-Sized Shirt}

The following is the result of FGD by experts mentioned in the generated codes.

\begin{tabular}{|c|c|}
\hline Sources & Object 3 \\
\hline \multirow[t]{2}{*}{ Research Subject 1} & \\
\hline & $\mathrm{KA}=$ shirts made under Komarudin system \\
\hline Observation Result of DA & $\begin{array}{l}\text { - Body circumferences is well-fitted. } \\
\text { - Waist circumference is too tight. } \\
\text { - Hip circumference is too tight. } \\
\text { - Pocket placement tilts. } \\
\text { - Shirt length is well-fitted }\end{array}$ \\
\hline Observation Result of DT & $\begin{array}{l}\text { - Body circumference is well-fitted. } \\
\text { - Body circumferences is well-fitted. } \\
\text { - Pocket placement tilts up. } \\
\text { - Shirt length is well-fitted. }\end{array}$ \\
\hline Observation Result of DK & $\begin{array}{l}\text { - Body circumferences is well-fitted. } \\
\text { - Body circumference is well-fitted. } \\
\text { - Hip circumference is well-fitted. } \\
\text { - Pocket placement tilts up. } \\
\text { - Shirt length is well-fitted. }\end{array}$ \\
\hline \multicolumn{2}{|l|}{ Research Subject 2} \\
\hline Observation Result of DA & $\begin{array}{l}\text { - Collar position is good. } \\
\text { - Collar shape is too big. } \\
\text { - Neck circumference is good. }\end{array}$ \\
\hline Observation Result ofDT & $\begin{array}{l}\text { - Collar position is exactly in shoulder pad. } \\
\text { - Collar shape is fitted enough. } \\
\text { - Neck circumference is too tight. }\end{array}$ \\
\hline Observation Result ofDK & $\begin{array}{l}\text { - Collar position is well-fitted. } \\
\text { - Collar shape is fairly good. } \\
\text { - Neck circumference in neck is too wide. }\end{array}$ \\
\hline Research Subject 3 & \\
\hline
\end{tabular}




\begin{tabular}{|c|c|}
\hline Observation Result ofDA & $\begin{array}{l}\text { - Back width is exactly in shoulder pad. } \\
\text { - Shoulder pad is enough. }\end{array}$ \\
\hline Observation Result ofDT & $\begin{array}{l}\text { - Back width is exactly in shoulder pad. } \\
\text { - Shoulder pad tilts slightly up. }\end{array}$ \\
\hline Observation Result ofDK & $\begin{array}{l}\text { - Back width is exactly in shoulder pad. } \\
\text { - Shoulder pad tilts slightly up. }\end{array}$ \\
\hline Research Subject 4 & $c \nabla$ \\
\hline Observation Result ofDA & $\begin{array}{l}\text { - Sleeve length is well-fitted. } \\
\text { - Sleeve circumference is good. } \\
\text { - Wiest circumference is well-fitted }\end{array}$ \\
\hline Observation Result ofDT & $\begin{array}{l}\text { - Sleeve length is too short. } \\
\text { - Sleeve circumference is too narrow. } \\
\text { - Wrist circumference is very tight. }\end{array}$ \\
\hline Observation Result ofDK & $\begin{array}{l}\text { - Sleeve length is too short. } \\
\text { - Sleeve circumference is well-fitted. } \\
\text { - Wrist circumference is well-fitted. }\end{array}$ \\
\hline
\end{tabular}

\section{c. Analysis result of M-Sized Shirt}

\begin{tabular}{|l|l|}
\hline \multicolumn{1}{|c|}{ Sources } & Object 3 \\
\hline Research Subject 2 & \\
& \\
& \\
\hline Observation Result ofDA & $\bullet$ Body circumference is well-fitted. \\
\hline
\end{tabular}


- Waits circumference iswell-fitted.

- Hip circumference is well-fitted.

- Pocket placement is precise.

- Shirt length is well-fitted.

Observation Result ofDT $\quad$ • Body circumference is very loose.

- Waits circumference is well-fitted.

- Hip circumference is well-fitted.

- Pocket placement is precise and suitable.

- Shirt length is well-fitted

\begin{tabular}{|c|c|}
\hline Observation Result ofDK & - Body circumference is well-fitted \\
\hline
\end{tabular}

- Waits circumference iswell-fitted.

- Hip circumference is well-fitted.

- Pocket position is precise.

- Shirt length is well-fitted.

\begin{tabular}{|c|c|}
\hline Research Subject 2 & \\
\hline Observation Result ofDA & $\begin{array}{l}\text { - Collar position is well-fitted. } \\
\text { - Collar shape is too big. } \\
\text { - Neck circumference is well-fitted. }\end{array}$ \\
\hline Observation Result ofDT & $\begin{array}{l}\text { - Collar position is precisely in shoulder pad. } \\
\text { - Collar shape is suitable. } \\
\text { - Neck circumferences is well-fitted. }\end{array}$ \\
\hline Observation Result ofDK & $\begin{array}{l}\text { - Collar position is precisely in well-fitted. } \\
\text { - Collar shape is suitable. } \\
\text { - Neck circumference is too big }\end{array}$ \\
\hline Research Subject 3 & $c$ \\
\hline Observation Result ofDA & $\begin{array}{l}\text { - } \text { Back width is precisely in shoulder pad. } \\
\text { - Shoulder pad. is enough }\end{array}$ \\
\hline Observation Result ofDT & $\begin{array}{l}\text { - Back width is precisely in shoulder pad. } \\
\text { - Shoulder pad is enough. }\end{array}$ \\
\hline Observation Result ofDK & $\begin{array}{l}\text { - Back width is precisely in shoulder pad. } \\
\text { - Shoulder pad is enough. }\end{array}$ \\
\hline
\end{tabular}




\begin{tabular}{|l|l|}
\hline Research Subject 4 & \\
& \\
& \\
\hline Observation Result ofDA & $\begin{array}{l}\text { - Sleeve length is well-fitted and suitable. } \\
\text { - Sleeve circumference is well-fitted and suitable } \\
\text { - Wrist circumference is well-fitted. }\end{array}$ \\
\hline Observation Result ofDT & $\begin{array}{l}\text { - Sleeve length is well-fitted and suitable. } \\
\text { - Sleeve circumference is enough. } \\
\text { - Wrist circumference is fairly loose. }\end{array}$ \\
\hline Observation Result ofDK & $\begin{array}{l}\text { - Sleeve length is well-fitted. } \\
\text { - Sleeve circumference is slightly loose. } \\
\text { - Wrist circumference is well-fitted. }\end{array}$ \\
\hline
\end{tabular}

\section{d. Analysis Result of L-Sized Shirt}

\begin{tabular}{|c|c|}
\hline Sources & Object 3 \\
\hline Research Subject 3 & \\
\hline Observation Result ofDA & $\begin{array}{l}\text { - Body circumference is well-fitted. } \\
\text { - Waist circumference is well-fitted. } \\
\text { - Hip circumference is well-fitted. } \\
\text { - Pocket placements tilts towards the midpoint. } \\
\text { - Shirt length is well-fitted. }\end{array}$ \\
\hline Observation Result ofDT & $\begin{array}{l}\text { - Body circumference is well-fitted. } \\
\text { - Waist circumference is well-fitted. } \\
\text { - Hip circumference is too tight. } \\
\text { - Pocket placement is tilts up. } \\
\text { - Shirt length is too long. }\end{array}$ \\
\hline Observation Result ofDK & $\begin{array}{l}\text { - Body circumference is well-fitted. } \\
\text { - Waist circumference is well-fitted. } \\
\text { - Hip circumference is well-fitted. } \\
\text { - Pocket placements tilts towards the midpoint. } \\
\text { - Shirt length is too long. }\end{array}$ \\
\hline Research Subject 2 & \\
\hline
\end{tabular}




\begin{tabular}{|c|c|}
\hline Observation Result ofDA & $\begin{array}{l}\text { - Collar position is good. } \\
\text { - Collar shape is too big. } \\
\text { - Neck circumference is very tight. }\end{array}$ \\
\hline Observation Result ofDT & $\begin{array}{l}\text { - Collar position is tight. } \\
\text { - Collar shape is suitable enough. } \\
\text { - Neck circumference is tight. }\end{array}$ \\
\hline Observation Result ofDK & $\begin{array}{l}\text { - Collar position tilts sharply up. } \\
\text { - Collar position is suitable. } \\
\text { - Neck circumference is tight. }\end{array}$ \\
\hline Research Subject 3 & \\
\hline Observation Result ofDA & $\begin{array}{l}\text { - Back width is precisely in shoulder pad. } \\
\text { - Shoulder pad is enough. }\end{array}$ \\
\hline Observation Result ofDT & $\begin{array}{l}\text { - Back width is precisely in shoulder pad. } \\
\text { - Shoulder pad is enough. }\end{array}$ \\
\hline Observation Result ofDK & $\begin{array}{l}\text { - Back width is precisely in shoulder pad. } \\
\text { - Shoulder pad is enough. }\end{array}$ \\
\hline Research Subject 4 & \\
\hline Observation Result ofDA & $\begin{array}{l}\text { - Sleeve length is too long. } \\
\text { - Sleeve circumference is very loose. } \\
\text { - Wrist circumference is very loose. }\end{array}$ \\
\hline Observation Result ofDT & $\begin{array}{l}\text { - Sleeve length is too long. } \\
\text { - Sleeve circumference is suitable. }\end{array}$ \\
\hline
\end{tabular}




\begin{tabular}{|l|l|}
\hline & $\bullet$ Wrist circumference is well-fitted. \\
\hline Observation Result ofDK & $\bullet$ Arm sleeve is too long. \\
& • Sleeve circumference is very loose. \\
& $\bullet$ Wrist circumference is well-fitted. \\
\hline
\end{tabular}

\section{e. Interview Data}

Question: What do you say about fitting factors of each shirt made under its respective system?

\section{(W/DA, DT,DK/KA)}

S-Sized Shirts. The shirt made under this system looks fit, but its neck circumference is too narrow. Besides, its back width as well as its shoulder width is wellfitted although its sleeve circumference is not good and causes a wrinkle to appear.Its loose enough body circumference is pulled by narrow armholes. What looks good is the position of collars; however, overall, it looksuntidiy because the pockets tilt sideways. (W/DA, DT,DK/KA)

M-Sized Shirts. This shirt has well-fitted body circumference. Its weak point lies in its neckline: it is placed too high and is too tight. What is more, the collar has unequal sizebetween the two sides and looks too long at the edge. In its application to M-sized shirts, what is best of this system is the balance between body circumference and shirt length.

(W/DA, DT,DK/KA)

L-Sized Shirts. The shirt under this system is made in appropriate size and well-fitted circumference.In fact, it looks the tidiest of all the L-sized shirts. Unfortunately, it has such weaknessesas too tight neckline and pointed edge of its collar, thereby looking unbalanced. As a matter of fact, seen from the back side, it is wide enough to make seam wrinkles to appear.Generally, narrow-enough sleeve circumferences also contribute greatly to this poor condition.

\section{DISCUSSION}

The researcher will subsequently describe and discuss dress shirts constructional made in $\mathrm{S}, \mathrm{M}$, and $\mathrm{L}$ sizes under Komarudin system applied to standard, sleeved, collared shirts with a pocket on the left chest.The data about fitting factor is obtained from the shirt parts.

Based on the analysis result, the shirts made under Komarudin's pattern making system in terms of their fitting factorshave 1) well-fitted body circumference, 2) too tight sleeve circumference, and 3) well-fitted neck circumference despite their small collar shape.

Fit measurements greatly affect the quality of fashion products such as dress shirts. Fitting factorsform a focal point of garment products from which to determine whether or not a fashion product made under a particular pattern-making system fits body measurements of people wearing it.As mentioned on https://fitinline.com/article., it can be concluded that whether a fashion product fits body measurements of its potential users depends largely on the accuracy and precision of its fitting factors.
Komarudin's shirt-making system uses the largest body measurements with added extra of $4 \mathrm{~cm}$ and the set shoulder pad, so that it yields neither too loose nor too tight products. Ariani,G.(2012) stated that basic patterns constitute the first step in the garment-making process with irritable steps both professional and amateur Taylors must follow. This means accurate measurements and proper method uses will provides beneficial results of good shirt products. Komarudin's pattern-making system has more detailed steps.Under this system, waist models are made in proportion to waist circumference with the particularly set looseness. In other words, the pattern of the waistis made $2 \mathrm{~cm}$ less than the body circumference, not straight flat as in common shirts.Such is an effort to produce shirts comfortable to wear - neither too tight nor too loose. In reality, many people wear ill-fit fashion products in that there is no right combination of designs and proportion with perfect fit between fashion products and body measurements of people wearing them, which in turns is cold comfort for them(http://mastyle-liesse).

Shirts have different size in the front sleeve and the back one, but such difference does not exist in the pattern because both parts of sleeves are made in one similar pattern of sleeves. On the contrary, under the system, front sleeves are made more curved than the back ones to enable further calculations and measurements. As for collars, the system draws pattern of collars away from theirboard, and the collars are given pointed edges. Measuring systems have decisive influences on the pattern produced. Masruroh (2012) mentioned that making a pattern under deafen systems and techniques will significantly affect fashion products yielded.Meanwhile, necklines are given added extras. In this term, the middle and front parts of the neckline are given extras different in sizes from other parts near to shoulders. It is such difference that causes collars not to ride up the shoulder.

\section{CONCLUSION AND SUGGESTION}

\subsection{Conclusion}

In conclusion, in terms of fitting factors, funder Komarudin's pattern making system are considered to be practical and suitable to be applied in shirt making process, for based on our research findings, shirts made under this system has the desired level of fit in almost all their fitting factors, including (1) necklines (2) back width, (3) body circumference, (4) waist circumference, (5) sleeves, and (6) wrist circumference. The only part missing its fitting factor is the shoulder pad, considered to tilt slightly up. After all, it can be said that Komarudin's pattern can be applied in making shirts in S, M, and L sizes. 


\subsection{Suggestion}

According to the research result and discussion above, the researcher comes up with a suggestion that Komarudin's shirt pattern is a good pattern on account of its intricate steps. However, theweak point of this pattern lies in its collar which tends to be so much in a pointed shape. Therefore, it is suggested for the collar to be reduced so as to fit the neckline and any other parts.

\section{REFERENCES}

[1] Achmadi, Ali. 2008. Konstruksi Dasar Pakaian Pria. Malang. Dinas Tenaga Kerja, Transmigrasi dan Kependudukan.

[2] Hadijah,Idah, 2000. Busana Pria. Bahan Ajar Program Studi Tata Busana Jurusan Teknologi Industri. Universitas Negeri Malang.

[3] http://fitinline.com. Perbedaan- berbagaimetode-pembuatan-pola. 21 Agustus 2014. Diakses, 15 Nov 1988

[4] http: ://journal unnes.ac.ac.id. Komparasi hasil pembuatan kemeja menggunakan pola sistem MH. Wancik dan sistim Soekarno. Masruroh. IPI Unnes

[5] Joseph, Helen Amstrong. 2010. Patternmaking for Fashion Design, New Jersey 07458. Pearson Education, Inc . Publishing.

[6] Komarudin, ..., Modul Pelatihan Menjahit Program Dispora. Kabupaten Banyuwangi.

[7] Murbeng Timur, Frieska. 2011. Analisa Hasil Pola Draping dan Pola Meyneke pada Pembuatan Kebaya Pesta. karyailmiah.um.ac.id > Halaman Awal > 2011 > tim

[8] Muliawan, Porie. 1999. Konstruksi Pola dan Busana Wanita. Jakarta: PT. BPK. Gunung Mulia.

[9] Pratiwi, Djati dkk. 2001. Pola Dasar dan Pecah Pola Busana. Yogyakarta: Kanisius.

[10] Poeradisastra, R. 2002. Busana Pria Eksekutif. Jakarta: PT. Gramedia Pustaka.

[11] Soekarno, 2008. Buku Penuntun Membuat Pola Busanat Tingkat Dasar. PT. Gramedia Pustaka Utama, Jakarta.

[12] Wancik, 1997. Pelajaran Menjahit Pakaian Pria, Jakarta: Gramedia Pustaka Utama. 